\title{
PENGEMBANGAN APLIKASI WEB BERBASIS FLEXBOX UNTUK PENGELOLAAN JADWAL PRODUKSI DAN DOKUMEN DIGITAL MENGGUNAKAN FRAMEWORK BULMA DI PT. GRAMEDIA
}

\author{
Goldie Gunadi \\ Program Studi Teknik Informatika STMIK Widuri Jakarta, Indonesia \\ E-mail: send2goldie@gmail.com
}

\begin{abstract}
PT. Gramedia is the largest printing service provider company in Indonesia. Besides in Jakarta, PT. Gramedia also opened several branches / sites in several regions, namely: Cikarang, Bandung, Surabaya, Medan, Bawen, Bali, Makassar and Palembang. The problem in this research is the process of delivering production schedule information and sending digital documents which are still carried out by production administration officers using fax machines, electronic mail (e-mail) and also messaging applications such as whatsapp. So that the production process at each site can run and well-coordinated applications are needed that can handle the production process and digital documents in PDF format that are needed as supporting information for centralized production. The application made consists of flexbox-based web applications and can be accessed by every user quickly and easily. The Bulma framework is needed so that the web application development process becomes faster and more efficient, because Bulma provides various libraries and web application components needed. The resulting web application can solve the problem of PT. Gramedia, easy to use, has a responsive display with an attractive layout and has compatibility with various mobile devices in use today.
\end{abstract}

Keywords: Web Application, Bulma Framework, Flexbox, Responsive

\begin{abstract}
ABSTRAK
PT. Gramedia adalah sebuah perusahaan penyedia jasa cetak yang terbesar di Indonesia. Selain di Jakarta, PT. Gramedia juga membuka sejumlah cabang/site di beberapa daerah, yaitu : Cikarang, Bandung, Surabaya, Medan, Bawen, Bali, Makassar dan Palembang. Permasalahan dalam penelitian ini ialah proses penyampaian informasi jadwal produksi dan pengiriman dokumen digital masih dilakukan secara menual oleh petugas administrasi produksi menggunakan mesin fax, surat elektronik (e-mail) dan juga aplikasi pengiriman pesan seperti whatsapp. Agar proses produksi di setiap site dapat berjalan dan terkoordinasi dengan baik dibutuhkan sebuah aplikasi yang dapat mengelola jadwal proses produksi dan dokumen-dokumen digital dengan format PDF yang diperlukan sebagai informasi pendukung produksi secara terpusat. Aplikasi yang dibuat berupa aplikasi web yang berbasis flexbox dan dapat diakses oleh setiap pengguna dengan cepat dan mudah. Framework Bulma diperlukan agar proses pengembangan aplikasi web menjadi lebih cepat dan efisien, karena Bulma menyediakan berbagai pustaka dan komponen-komponen aplikasi web yang dibutuhkan. Aplikasi web yang dihasilkan dapat mengatasi permasalahan PT. Gramedia, mudah digunakan, memiliki tampilan yang responsif dengan layout yang menarik serta memiliki kompatibilitas dengan berbagai perangkat mobile yang digunakan saat ini.
\end{abstract}

Kata Kunci: Aplikasi Web, Framework Bulma, Flexbox, Responsif

\section{PENDAHULUAN}

Didirikan pada tahun 1972 sebagai salah satu unit bisnis Kompas Gramedia, PT. Gramedia telah membuktikan dirinya sebagai salah satu perusahaan penyedia jasa cetak terkemuka di Indonesia.
PT. Gramedia yang kini lebih dikenal dengan nama Gramedia Printing terus mengembangkan bisnisnya, baik di Indonesia maupun di pasar Internasional. Berbagai jenis produk cetak yang dihasilkan oleh PT. Gramedia diantaranya adalah berupa surat kabar/koran, tabloid, majalah, buku, material promosi dan lain-lain. 
PT. Gramedia berpusat di Palmerah, Jakarta dan untuk memenuhi kebutuhan konsumennya, PT. Gramedia juga membuka sejumlah cabang/site di beberapa daerah, yaitu: Cikarang, Bandung, Surabaya, Medan, Bawen, Bali, Makassar dan Palembang.

Permasalahannya adalah, proses penyampaian informasi jadwal produksi dan pengiriman dokumen digital masih dilakukan secara menual oleh petugas administrasi produksi menggunakan mesin fax, surat elektronik (e-mail) dan juga aplikasi pengiriman pesan seperti whatsapp. Hal ini mengakibatkan proses pengendalian dan pengelolaan terhadap informasi jadwal serta dokumen-dokumen digital pendukung proses produksi tersebut menjadi sulit karena dikelola oleh masing-masing site secara terpisah. Proses tersebut akan menjadi lebih lama apabila terdapat revisi terhadap jadwal dan/atau informasi produksi serta permintaan ulang data/informasi dari site ke pusat. Untuk mengatasi hal tersebut diperlukan sebuah aplikasi yang dapat mengelola jadwal produksi dan dokumen-dokumen digital pendukung produksi yang diperlukan oleh setiap site. Site dapat melihat jadwal dan juga informasi produksi setiap saat secara cepat dan dimana saja. Dokumen-dokumen digital disajikan dalam bentuk dokumen PDF sehingga dapat mudah diakses oleh setiap perangkat baik PC maupun laptop/notebook.

Tujuan dari penelitian ini untuk memastikan proses produksi berjalan sesuai dengan permintaan konsumen, percetakan pusat (Jakarta) akan melakukan penjadwalan proses produksi dan mendistribusikan data atau informasi konfigurasi halaman cetak dan surat perintah kerja (SPK) produksi yang berupa dokumen digital ke masing-masing site yang memerlukannya.

Framework Bulma adalah sebuah framework CSS yang dapat digunakan untuk membuat sebuah aplikasi website berbasis flexbox (flexible box) secara mudah dan cepat karena framework tesebut menyediakan berbagai macam komponen serta fitur-fitur yang dibutuhkan dalam pembuatan website. Penggunaan framework Bulma diharapkan dapat mempercepat proses pembuatan aplikasi penjadwalan dan pengelolaan dokumen digital proses produksi yang dibutuhkan oleh PT. Gramedia, disamping itu juga menjadikan tampilan aplikasi lebih menarik, responsif serta mudah digunakan oleh pemakai (Sidik, n.d.) (Somya \& Nathanael, 2019).

\section{METODE PENELITIAN}

Unified Modeling Language (UML) adalah suatu bahasa yang digunakan untuk menentukan, memvisualisasikan, membangun, dan mendokumentasikan suatu sistem informasi atau perangkat lunak. UML dikembangkan sebagai suatu alat untuk analisis dan desain berorientasi objek (James Rumbaugh, Ivar Jacobson, 1999).

UML adalah himpunan struktur dan teknik untuk pemodelan desain program berorientasi objek (OOP) serta aplikasinya (Sani, 2018).

UML adalah metodologi untuk mengembangkan sistem OOP dan sekelompok perangkat tool untuk mendukung pengembangan sistem tersebut. UML mulai diperkenalkan oleh Object Management Group, sebuah organisasi yang telah mengembangkan model, teknologi, dan standar OOP sejak tahun 1980-an. Sekarang UML sudah mulai banyak digunakan oleh para praktisi OOP. UML merupakan dasar bagi perangkat (tool) desain berorientasi objek dari IBM. Namun demikian UML dapat digunakan untuk memahami dan mendokumentasikan setiap sisteminformasi. Penggunaan UML dalam industri terus meningkat. Ini merupakan standar terbuka yang menjadikannya sebagai bahasa pemodelan yang umum dalam industri peranti lunak dan pengembangan sistem (Munawar, 2018).

Sebuah aktivitas dapat direalisasikan oleh satu use case atau lebih. Aktivitas menggambarkan proses yang berjalan, sementara use case menggambarkan bagaimana aktor menggunakan sistem untuk melakukan aktivitas. Decision digunakan untuk menggambarkan behaviour pada kondisi tertentu. Untuk mengilustrasikan prosesproses paralel (fork dan join) digunakan titik sinkronisasi yang dapat berupa titik, garis horizontal atau vertikal. Diagram Activity dapat dibagi menjadi beberapa object swimlane untuk menggambarkan objek mana yang bertanggung jawab untuk aktivitas tertentu.

\section{HASIL DAN PEMBAHASAN}

Berikut adalah hasil dari proses analisa dan pengambangan perangkat lunak

\section{Identifikasi Kebutuhan Pengguna}

Berikut adalah kebutuhan fungsional dan non fungsional perangkat lunak :

\section{Kebutuhan Fungsional}

a. Terdapat prose login dan logout pengguna.

b. Terdapat 2 tipe pengguna, yaitu : pengguna biasa dan administrator.

c. Pengguna biasa dan administrator dapat melihat planboard dan melihat file digital.

d. Administrator dapat mengelola jadwal mesin dan dokumen digital.

e. Administrator dapat mengelola master data : site, mesin, produk dan pengguna

2. Kebutuhan Non Fungsional a. Menggunakan DBMS : SQL Server 2008. 
b. Aplikasi berbasis web menggunakan bahasa pemrograman PHP dan Apache Web Server.

c. Dapat diakses menggunakan komputer desktop maupun laptop.

d. Dapat dijalankan menggunakan browser Google Chrome dan Mozilla Firefox.

e. Data digital dalam bentuk dokumen format PDF dan dapat diakses/ditampilkan melalui browser.

f. Menggunakan arsitektur JSON dalam proses pengiriman data yang berasal dari basis data ke halaman tampilan web.

g. Tampilan halaman web yang responsif dan mudah digunakan.

\section{Rancangan Diagram UML}

\section{Diagram Use Case}

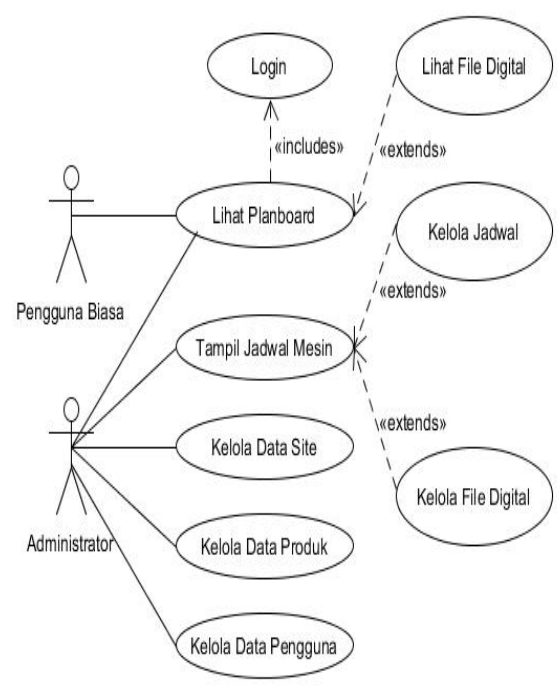

Sumber : (Goldie Gunadi, 2019)

Gambar 1. Diagram Use Case

\section{Diagram Activity}

a. Diagram Activity Planboard

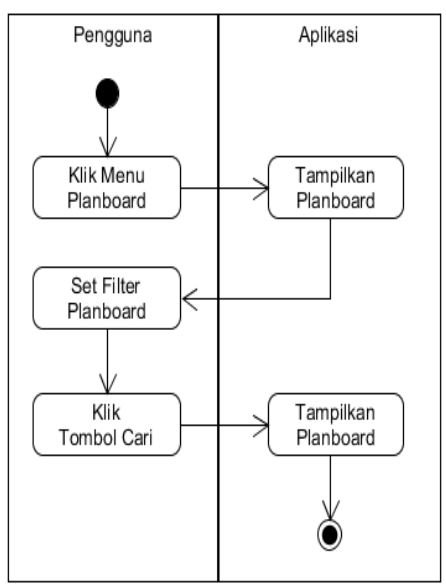

Sumber : (Goldie Gunadi, 2019)

Gambar 2. Diagram Activity Planboard b. Diagram Activity Kelola Jadwal Mesin

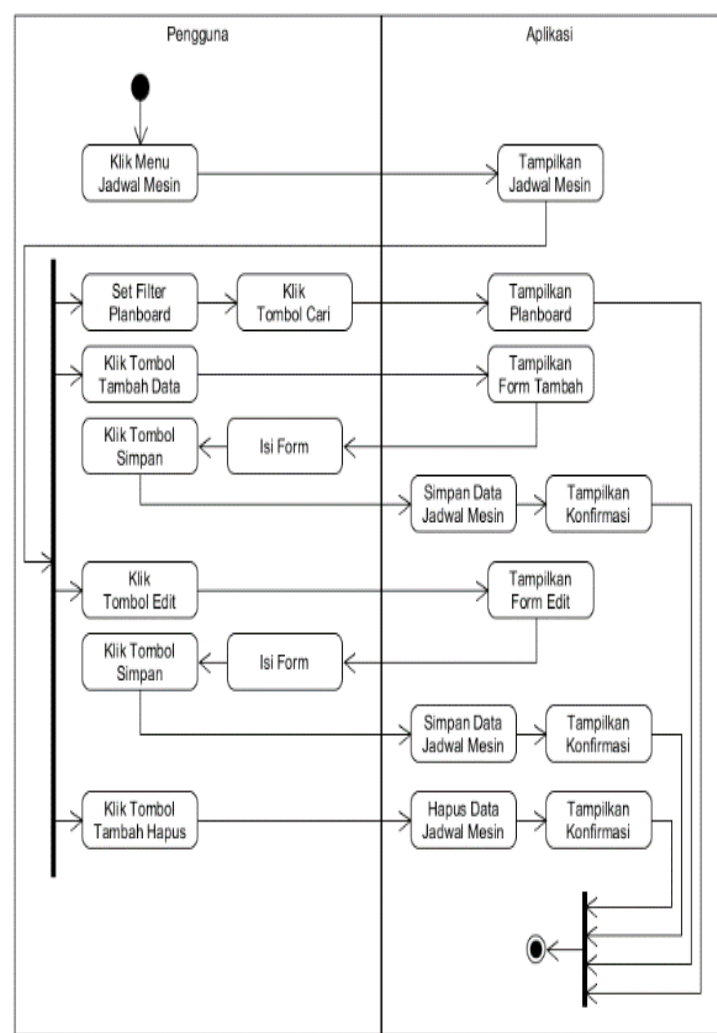

Sumber : (Goldie Gunadi, 2019)

Gambar 3. Diagram Activity Kelola Jadwal Mesin

c. Diagram Activity Lihat File Digital

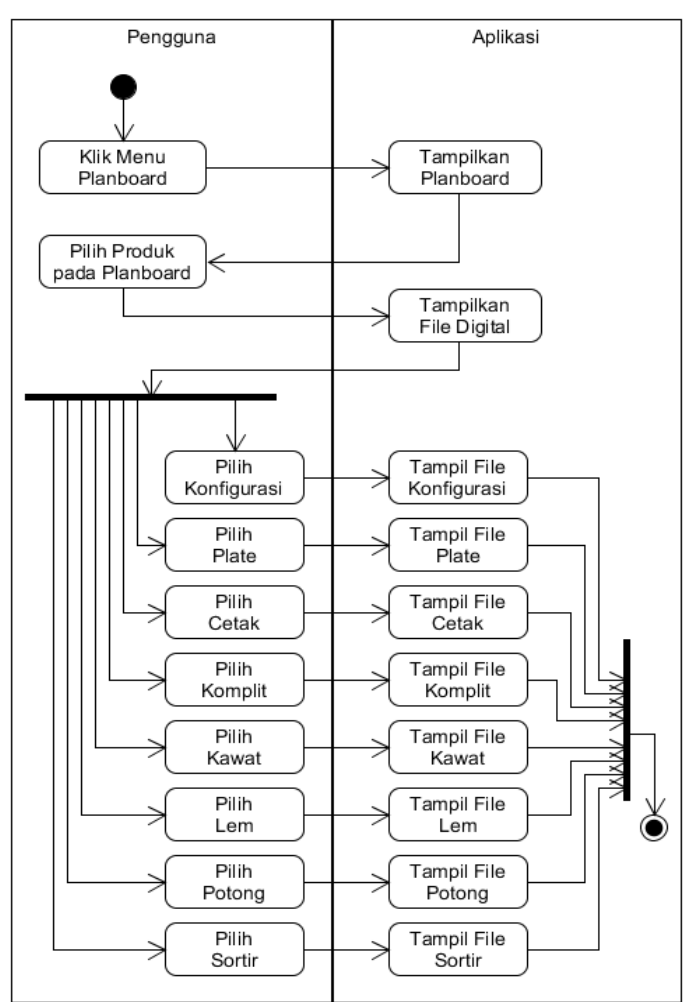

Sumber : (Goldie Gunadi, 2019)

Gambar 4. Diagram Activity Lihat File Digital 
d. Diagram Activity Kelola File Digital

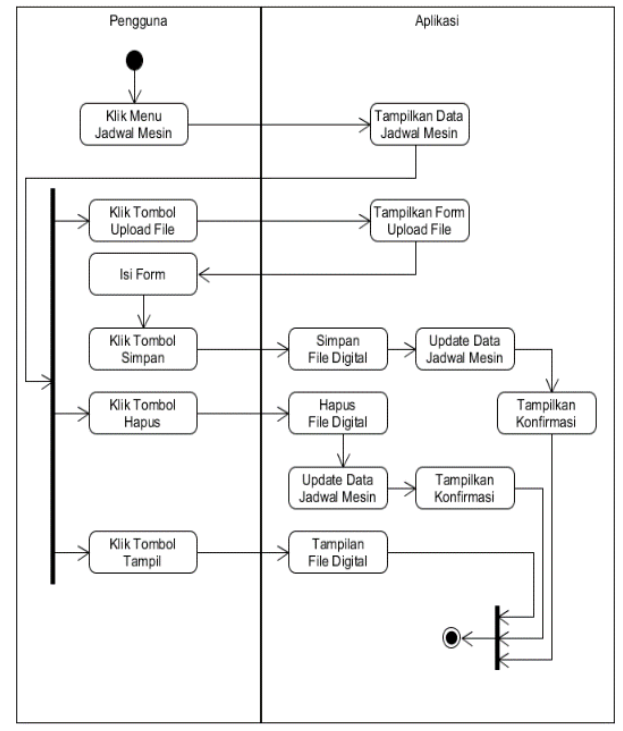

Sumber : (Goldie Gunadi, 2019)

Gambar 5. Diagram Lihat Kelola File Digital

\section{Diagram Sequence}

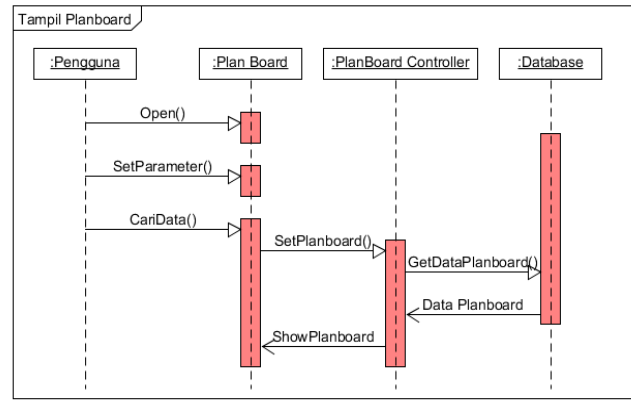

Sumber : (Goldie Gunadi, 2019)

Gambar 6. Diagram Sequence Planboard

a. Diagram Sequence Lihat File Digital

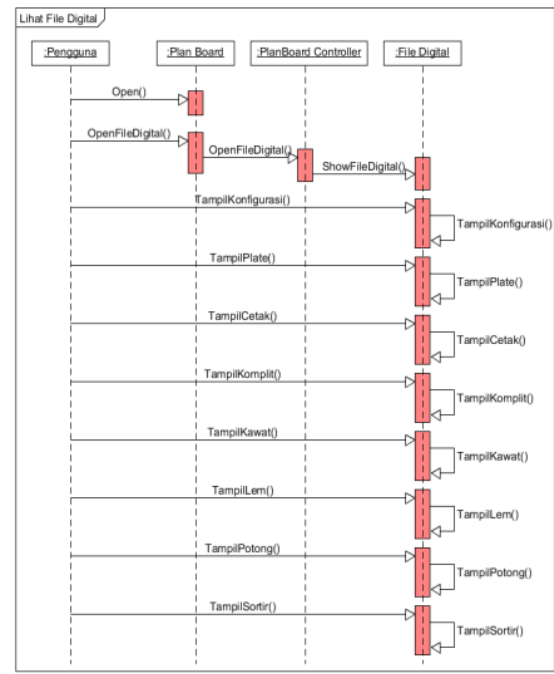

Sumber : (Goldie Gunadi, 2019)

Gambar 7. Diagram Sequence Lihat File Digital b. Diagram Sequence Kelola Jadwal Mesin

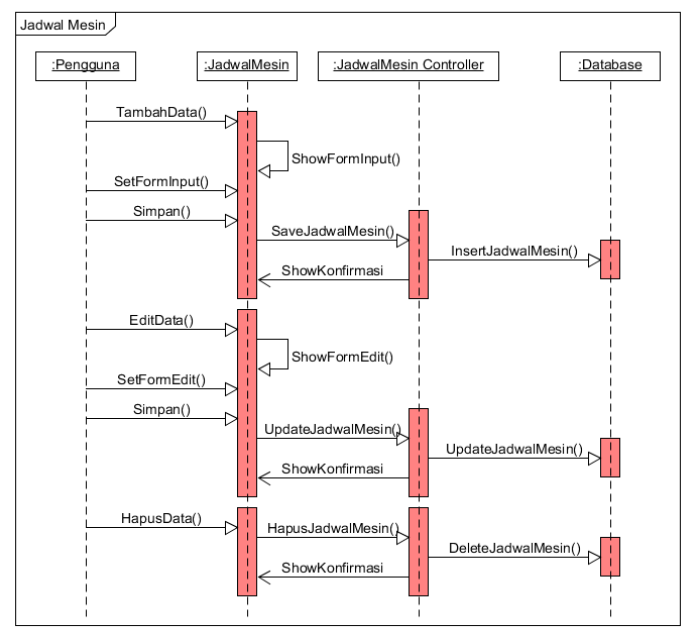

Sumber : (Goldie Gunadi, 2019)

Gambar 8. Diagram Sequence Lihat File Digital

c. Diagram Sequence Kelola File Digital

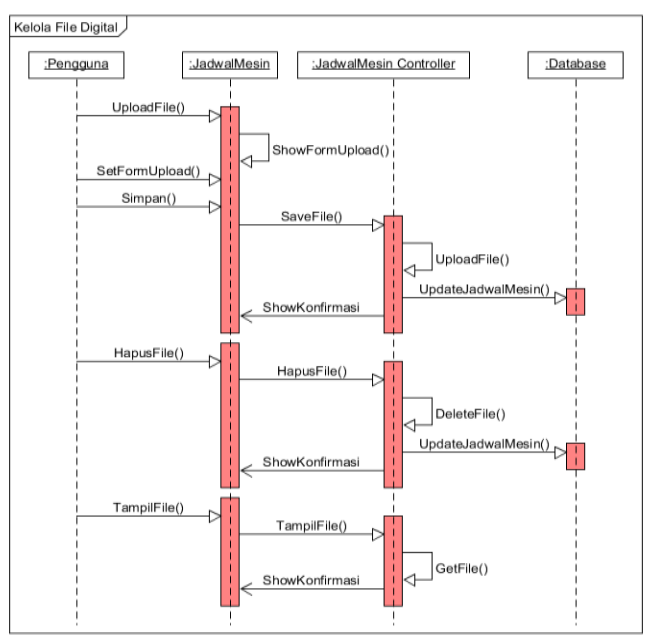

Sumber : (Goldie Gunadi, 2019)

Gambar 9. Diagram Sequence Kelola File Digital

\section{Diagram Relasi Basis Data}

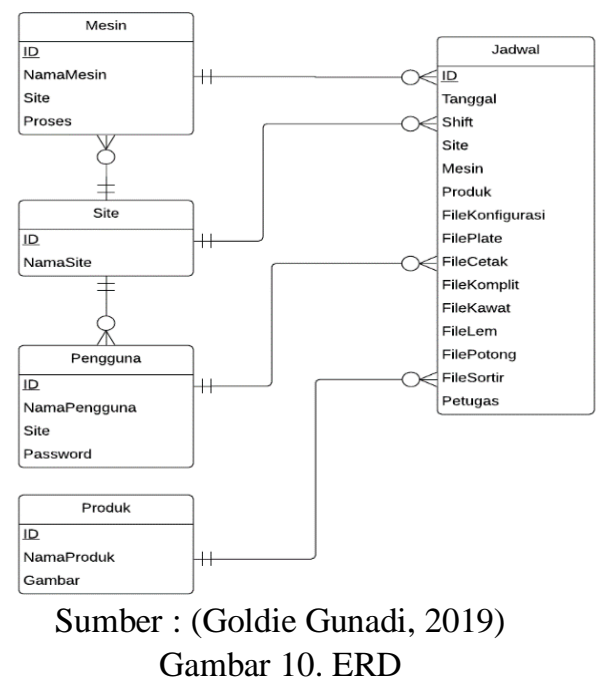




\section{Tampilan Login}

\section{Login Pengguna}

Login

Sumber : (Goldie Gunadi, 2019)

Gambar 11. Tampilan Antarmuka Login Pengguna

Tampilan Menu Utama

JOODiE Plan board Jadwal Mesin Master Data $v$ Pengguna

Data Produk

Data Site

Data Mesin

Sumber : (Goldie Gunadi, 2019)

Gambar 12. Tampilan Antarmuka Menu Utama

\section{Tampilan Planboard}

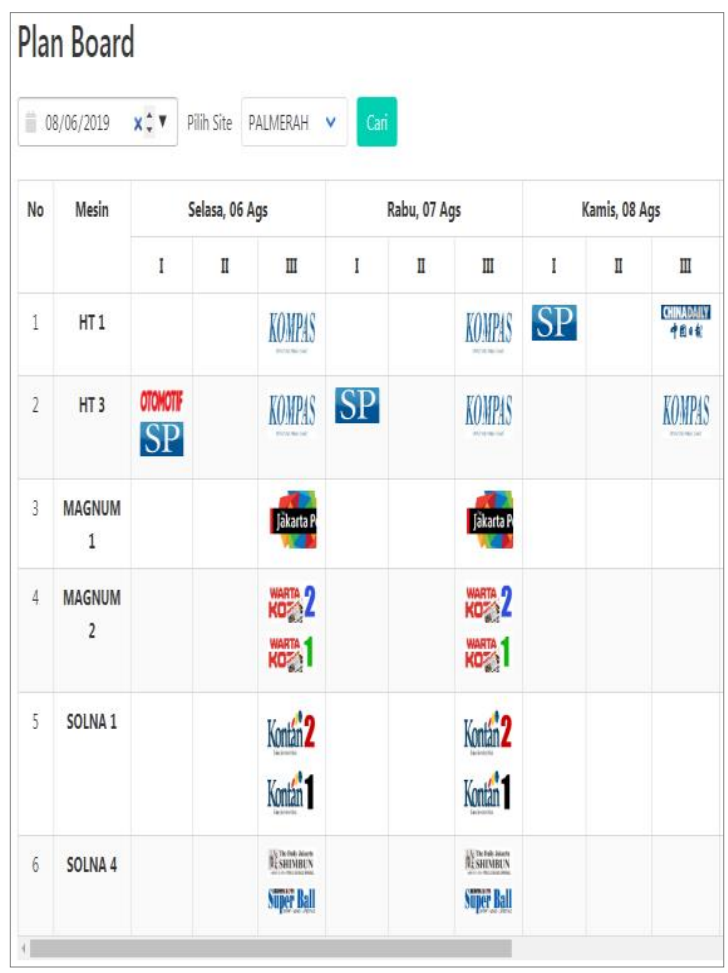

Sumber : (Goldie Gunadi, 2019)

Gambar 13. Tampilan Antarmuka Planboard

\section{Pengujian Aplikasi}

Pengujian aplikasi dilakukan dengan menggunakan metode Black Box.

\section{Pengujian Login}

Tabel 1. Hasil Pengujian Login

\begin{tabular}{|l|l|l|}
\hline $\begin{array}{l}\text { Skenario } \\
\text { Pengujian }\end{array}$ & Hasil Diharapkan & $\begin{array}{l}\text { Hasil } \\
\text { Pengujian }\end{array}$ \\
\hline $\begin{array}{l}\text { Uji login } \\
\text { sukses }\end{array}$ & $\begin{array}{l}\text { Login berhasil masuk } \\
\text { ke halaman plaboard }\end{array}$ & $\begin{array}{l}\text { Sudah } \\
\text { Sesuai }\end{array}$ \\
\hline $\begin{array}{l}\text { Uji login } \\
\text { gagal }\end{array}$ & $\begin{array}{l}\text { Login gagal, } \\
\text { tampilkan konfirmasi. }\end{array}$ & $\begin{array}{l}\text { Sudah } \\
\text { Sesuai }\end{array}$ \\
\hline
\end{tabular}

Sumber :(Goldie Gunadi, 2019)

\section{Pengujian Planboard}

Tabel 2. Hasil Pengujian Planboard

\begin{tabular}{|l|l|l|}
\hline $\begin{array}{l}\text { Skenario } \\
\text { Pengujian }\end{array}$ & Hasil Diharapkan & $\begin{array}{l}\text { Hasil } \\
\text { Pengujian }\end{array}$ \\
\hline $\begin{array}{l}\text { Tampilkan } \\
\text { Planboard }\end{array}$ & $\begin{array}{l}\text { Tampilan planboard } \\
\text { berdasarkan tanggal } \\
\text { dan site default } \\
\text { terpilih. }\end{array}$ & $\begin{array}{l}\text { Sudah } \\
\text { Sesuai }\end{array}$ \\
\hline $\begin{array}{l}\text { Filter } \\
\text { planboard } \\
\text { berdasarkan } \\
\text { tanggal dan } \\
\text { site }\end{array}$ & $\begin{array}{l}\text { Tampilan planboard } \\
\text { berdasarkan filter } \\
\text { tanggal dan site. }\end{array}$ & $\begin{array}{l}\text { Sudah } \\
\text { Sesuai }\end{array}$ \\
\hline $\begin{array}{l}\text { Pilih Produk } \\
\text { pada } \\
\text { planboard } \\
\text { untuk } \\
\text { menampilkan }\end{array}$ & $\begin{array}{l}\text { Tampilan halaman } \\
\text { yang berisi tampilan } \\
\text { file digital untuk } \\
\text { produk yang dipilih. }\end{array}$ & $\begin{array}{l}\text { Sudah } \\
\text { Sesuai }\end{array}$ \\
\hline
\end{tabular}

Sumber : (Goldie Gunadi, 2019)

\section{Pengujian Lihat File Digital}

Tabel 3. Hasil Pengujian Lihat File Digital

\begin{tabular}{|l|l|l|}
\hline $\begin{array}{l}\text { Skenario } \\
\text { Pengujian }\end{array}$ & Hasil Diharapkan & $\begin{array}{l}\text { Hasil } \\
\text { Pengujian }\end{array}$ \\
\hline $\begin{array}{l}\text { Menampilkan } \\
\text { setiap } \\
\text { dokumen } \\
\text { digital PDF } \\
\text { sesuai produk } \\
\text { yang dipilih }\end{array}$ & $\begin{array}{l}\text { Tampilan dokumen } \\
\text { digital sesuai dengan } \\
\text { produk yang terpilih } \\
\text { pada }\end{array}$ & $\begin{array}{l}\text { Sudahboard.. } \\
\text { Tampilan file digital } \\
\text { dalam bentuk PDF. }\end{array}$ \\
planboard & & \\
\hline
\end{tabular}

Sumber : (Goldie Gunadi, 2019)

\section{Pengujian Jadwal Mesin}

Tabel 4. Hasil Pengujian Jadwal Mesin

\begin{tabular}{|l|l|l|}
\hline $\begin{array}{l}\text { Skenario } \\
\text { Pengujian }\end{array}$ & Hasil Diharapkan & $\begin{array}{l}\text { Hasil } \\
\text { Pengujian }\end{array}$ \\
\hline $\begin{array}{l}\text { Tampilkan } \\
\text { Jadwal Mesin }\end{array}$ & $\begin{array}{l}\text { Tampilan jadwal } \\
\text { mesin berdasarkan } \\
\text { tanggal dan site } \\
\text { default terpilih. }\end{array}$ & $\begin{array}{l}\text { Sudah } \\
\text { Sesuai }\end{array}$ \\
\hline
\end{tabular}




\begin{tabular}{|c|c|c|}
\hline $\begin{array}{l}\text { Filter jadwal } \\
\text { mesin } \\
\text { berdasarkan } \\
\text { tanggal dan } \\
\text { site }\end{array}$ & $\begin{array}{l}\text { Tampilan jadwal } \\
\text { mesin berdasarkan } \\
\text { filter tanggal dan } \\
\text { site. }\end{array}$ & $\begin{array}{l}\text { Sudah } \\
\text { Sesuai }\end{array}$ \\
\hline $\begin{array}{l}\text { Menambahkan } \\
\text { jadwal mesin }\end{array}$ & $\begin{array}{l}\text { Jadwal mesin } \\
\text { ditambahkan ke } \\
\text { dalam basis data. } \\
\text { Tampilan jadwal } \\
\text { mesin diperbaharui. } \\
\text { Menampilkan } \\
\text { konfirmasi. }\end{array}$ & $\begin{array}{l}\text { Sudah } \\
\text { Sesuai }\end{array}$ \\
\hline $\begin{array}{l}\text { Menghapus } \\
\text { jadwal mesin }\end{array}$ & $\begin{array}{l}\text { Jadwal mesin } \\
\text { dihapus dari dalam } \\
\text { basis data. Dokumen } \\
\text { digital yang } \\
\text { berhubungan dengan } \\
\text { jadwal tersebut juga } \\
\text { dihapus. Tampilan } \\
\text { jadwal mesin } \\
\text { diperbaharui. } \\
\text { Menampilkan } \\
\text { konfirmasi. }\end{array}$ & $\begin{array}{l}\text { Sudah } \\
\text { Sesuai }\end{array}$ \\
\hline $\begin{array}{l}\text { Melakukan } \\
\text { upload } \\
\text { dokumen } \\
\text { digital produk } \\
\text { terpilih pada } \\
\text { jadwal mesin } \\
\text { dalam bentuk } \\
\text { PDF. }\end{array}$ & $\begin{array}{l}\text { Dokumen digital } \\
\text { berhasil disimpan. } \\
\text { Pembaharuan data } \\
\text { jadwal mesin pada } \\
\text { basis data. } \\
\text { Tampilan jadwal } \\
\text { mesin diperbaharui. } \\
\text { Menampilkan } \\
\text { konfirmasi. }\end{array}$ & $\begin{array}{l}\text { Sudah } \\
\text { Sesuai }\end{array}$ \\
\hline $\begin{array}{l}\text { Menghapus } \\
\text { dokumen } \\
\text { digital produk } \\
\text { terpilih pada } \\
\text { jadwal mesin. }\end{array}$ & $\begin{array}{l}\text { Dokumen digital } \\
\text { berhasil dihapus. } \\
\text { Pembaharuan data } \\
\text { jadwal mesin pada } \\
\text { basis data. Tampilan } \\
\text { jadwal mesin } \\
\text { diperbaharui. } \\
\text { Menampilkan } \\
\text { konfirmasi. }\end{array}$ & $\begin{array}{l}\text { Sudah } \\
\text { Sesuai }\end{array}$ \\
\hline $\begin{array}{l}\text { Menampilkan } \\
\text { dokumen } \\
\text { digital produk } \\
\text { terpilih pada } \\
\text { jadwal mesin. }\end{array}$ & $\begin{array}{l}\text { Dokumen digital } \\
\text { ditampilkan pada } \\
\text { halaman baru. }\end{array}$ & $\begin{array}{l}\text { Sudah } \\
\text { Sesuai }\end{array}$ \\
\hline
\end{tabular}

Sumber : (Goldie Gunadi, 2019)

Pengujian Kelola Data Master (Data Site, Data Mesin, Data Produk, Data Pengguna)

Tabel 5 Hasil Pengujian Jadwal Mesin

\begin{tabular}{|l|l|l|}
\hline $\begin{array}{l}\text { Skenario } \\
\text { Pengujian }\end{array}$ & Hasil Diharapkan & $\begin{array}{l}\text { Hasil } \\
\text { Pengujian }\end{array}$ \\
\hline $\begin{array}{l}\text { Tampilkan } \\
\text { Kelola Data. }\end{array}$ & $\begin{array}{l}\text { Menampilkan data } \\
\text { dari basis data. } \\
\text { Menampilkan } \\
\text { konfirmasi. }\end{array}$ & $\begin{array}{l}\text { Sudah } \\
\text { Sesuai }\end{array}$ \\
\hline $\begin{array}{l}\text { Menambahkan } \\
\text { Data Site }\end{array}$ & $\begin{array}{l}\text { Menampilkan Form } \\
\text { Input. }\end{array}$ & $\begin{array}{l}\text { Sudah } \\
\text { Sesuai }\end{array}$ \\
\hline
\end{tabular}

\begin{tabular}{|c|c|c|}
\hline & $\begin{array}{l}\text { Menyimpan data ke } \\
\text { dalam basis data. } \\
\text { Tampilan Data Site } \\
\text { diperbaharui. } \\
\text { Menampilkan } \\
\text { konfirmasi. }\end{array}$ & \\
\hline $\begin{array}{l}\text { Mengubah } \\
\text { Data Site. }\end{array}$ & $\begin{array}{l}\text { Menampilkan Form } \\
\text { Edit. } \\
\text { Memperbaharui data } \\
\text { dalam basis data. } \\
\text { Tampilan Data } \\
\text { diperbaharui. } \\
\text { Menampilkan } \\
\text { konfirmasi. }\end{array}$ & $\begin{array}{l}\text { Sudah } \\
\text { Sesuai }\end{array}$ \\
\hline $\begin{array}{l}\text { Menghapus } \\
\text { Data Site. }\end{array}$ & $\begin{array}{l}\text { Menghapus data } \\
\text { dalam basis data. } \\
\text { Tampilan Data } \\
\text { diperbaharui. } \\
\text { Menampilkan } \\
\text { konfirmasi. }\end{array}$ & $\begin{array}{l}\text { Sudah } \\
\text { Sesuai }\end{array}$ \\
\hline
\end{tabular}

Sumber : (Goldie Gunadi, 2019)

\section{KESIMPULAN}

Kesimpulan pengambangan aplikasi web berbasis flexbox untuk pengelolaan jadwal produksi dan dokumen digital, diantaranya:

Aplikasi web berbasis flexbox memiliki tampilan yang lebih interaktif dan mudah digunakan serta dapat diakses oleh perangkat PC maupun laptop/notebook sehingga mempermudah pengguna dalam mengelola dan melihat jadwal produksi maupun dokumen digital. Penggunaan framework Bulma menjadikan proses pembuatan aplikasi lebih cepat dan mudah dan tampilan aplikasi menjadi lebih menarik dan responsif. Metode pertukaran data dengan format JSON digunakan untuk menyajikan data yang diperoleh dari basis data SQL Server ke tampilan aplikasi. Membuat aplikasi web menjadi lebih terstruktur dan mudah dikelola. Dengan adanya aplikasi ini mempermudah proses pengelolaan dokumen digital dengan format PDF menjadi lebih mudah, cepat dan efisien. Dan Applikasi dibuat dengan menggunakan dua hak akses yakni untuk pengguna biasa dan administrator, dimana masing-masing memiliki fungsi atau kewenangan yang berbeda, hal ini diperlukan dari sisi keamanan data.

\section{DAFTAR PUSTAKA}

Goldie Gunadi. (2019). Pengembangan Aplikasi Web Berbasis Flexbox Untuk Pengelolaan Jadwal Produksi Dan Dokumen Digital Menggunakan Framework Bulma DI PT. GRAMEDIA.

James Rumbaugh, Ivar Jacobson, and G. B. (1999). The Unified Modeling Language Reference Manual. Addison. 
Munawar. (2018). Analisis Perancangan Sistem Berorientasi Objek dengan UML (1st ed.). Informatika.

Sani, A. (2018). Analisa Penjualan Retail Dengan Metode Association Rule Untuk Association Rule Untuk Pengambilan Keputusan Strategis Perusahaan : 2(June 2016), 34-50.

Sidik, B. (n.d.). Pemrograman Web dengan PHP. In 2012. Informatika.

Somya, R., \& Nathanael, T. M. E. (2019). Pengembangan Sistem Informasi Pelatihan Berbasis Web Menggunakan Teknologi Web Service Dan Framework Laravel. Jurnal Techno Nusa Mandiri, 16(1), 51-58. https://doi.org/10.33480/techno.v16i1.164 
